\title{
THE BEBRAS CONTEST IN PRIMARY INFORMATICS
}

\section{Monika GUJBEROVÁ}

\begin{abstract}
In this article I am dealing with an informatics contest called Bebras, in Slovak "iBobor". This competition focuses on elementary and secondary school students. In the school year 2011/12 a new competition category called "Bobrík" appeared in Slovakia for the $3^{\text {rd }}$ and $4^{\text {th }}$ class elementary school pupils.

Since 2008, when a school reform took place, Informatics has been a compulsory subject from the $2^{\text {nd }}$ class of elementary schools in Slovakia. However there is still a lack of teaching materials. In my article I am offering some lesson plans in details. The aim of this article is to introduce to the teachers how to make use of some competition tasks appearing in previous years' iBobor. Particular lessons focused on the thematic sphere Problem-solving and algorithmic thinking.
\end{abstract}

Key words: Bebras Contest, Elementary Informatics in Primary Education, Algorithmic thinking

\section{iBOBOR V INFORMATICKEJ VÝCHOVE}

Resumé: V tomto článku sa venujem sútaži Informatický bobor: iBobor. Táto sút’až je určená pre žiakov základných a stredných škôl. Na Slovensku organizujeme od školského roku 2011/2012 aj novú sútažnú kategóriu Bobrík, ktorá je určená pre žiakov prvého stupňa základných škôl (konkrétne pre 3. a 4. ročník).

Od roku 2008, kedy prebehla na Slovensku školská reforma, je od druhého ročníka základnej školy povinný predmet informatická výchova. Avšak stále sme v stave, kedy učitelia nemajú dostatok učebných materiálov a učebníc. V článku ponúkam prípravu niekol'kých vyučovacích hodín a podrobný popis ich priebehu. Chcela by som aj takýmto spôsobom predstavit' učitel'om možnosti využitia niektorých sútažných úloh, ktoré boli v minulých rokoch v sútaži iBobor. Jednotlivé hodiny sú zamerané na tematický okruh Riešenie problémov a algoritmické myslenie.

Kl’účové slová: iBobor, informatická výchova, algoritmické myslenie.

\section{1 Úvod}

Informatický bobor - iBobor - je sút'až, ktorej úlohy sú určené pre žiakov základných a stredných škôl, pozri [1]. V školskom roku 2011/2012 sa sút’až konala v 17 krajinách (Česko, Estónsko, Fínsko, Francúzsko, Holandsko, Japonsko, Litva, Lotyšsko, Mad'arsko, Nemecko, Pol'sko, Rakúsko, Slovensko, Slovinsko, Švajčiarsko, Taliansko a Ukrajina), pozri [2]. V tomto roku sa zapojili aj d'alšie štáty. Od školského roku 2011/2012 sa na Slovensku objavila nová sút'ažná kategória pre prvý stupeň základných škôl (pre 3. a 4. ročník) Bobrik. Táto iniciatíva sa začína javit' ako dobrý nápad, ked’že tento rok sút'ažili aj žiaci prvého stupňa v Litve a v Českej republike.

Od roku 2008 máme na Slovensku nový povinný predmet informatická výchova, ktorý je povinný už od druhého ročníka základnej školy. V sút’ažných úlohách spomínanej sút’aže sa ukrýva obrovský potenciál, ktorý by sme chceli lepšie využit'. Ciel'om článku je predstavit' učitel'om možnosti využitia niektorých sútažných úloh $\mathrm{v}$ rámci hodín informatickej výchovy. $\mathrm{V}$ článku sa zameriavame na prípravu dvoch vyučovacích hodín s podrobným popisom ich priebehu a d'alšími námetmi na rozšírenie, ako vylepšit' tieto hodiny a na čo si dávat' pri ich výučbe pozor.

\section{Použité výskumné metódy}

V svojej práci som použila viaceré výskumné metódy na zber dát, ako zúčastnené a nepriame pozorovanie či skupinový rozhovor, pozri [3]. Hlavnou výskumnou metódou bolo pozorovanie. Nakol'ko som bola zúčastnená na vyučovacích hodinách ako vyučujúci, aj ako pozorovatel', potrebovala som zaznamenat' všetky dôležité udalosti, ktoré nastali počas vyučovania a ktoré som inak nemala možnost' postrehnút' a zapamätat'. Práve preto som sa rozhodla, že vytvorím videozáznam týchto hodín. Následne som tieto nahrávky analyzovala. Obe vyučovacie hodiny som začala motivačným rozhovorom. Na základe odpovedí žiakov som si mohla vytvorit' lepší 
obraz o tom, ako vnímajú žiaci danú tému a aké sú ich predošlé skúsenosti a vedomosti.

\section{Výber úloh pre prípravu dvoch vyučovacích hodín}

Z pilotného a prvého ročníka kategórie Bobrik som si vybrala niektoré úlohy, ktoré patria do tematického okruhu Riešenie problémov a algoritmické myslenie, t.j. také, ktoré podporujú rozvoj algoritmického myslenia. Vybrané úlohy sa volajú Hamburger, Kocky a Myš a syr, pozri Obr. 1, 4 a 8. Hamburger a Kocky sú úlohy zamerané na rozvoj schopností skladat' podl'a návodu. Pri úlohe Myš a syr si žiaci môžu precvičit' schopnost' riadit' robota. Tu však vzniká otázka, ako využit' tieto úlohy na bežnej vyučovacej hodine informatickej výchovy. Na zodpovedanie tejto otázky som hl'adala možnosti a vhodné nástroje, ktoré máju učitelia $\mathrm{k}$ dispozícii a s ktorými by mali vediet' narábat'.

V rýchlom občerstvení sme si kúpili hamburger. Vyzerá takto:

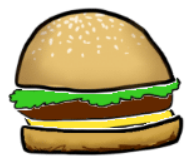

Ťahaním kartičiek priprav rovnaký.

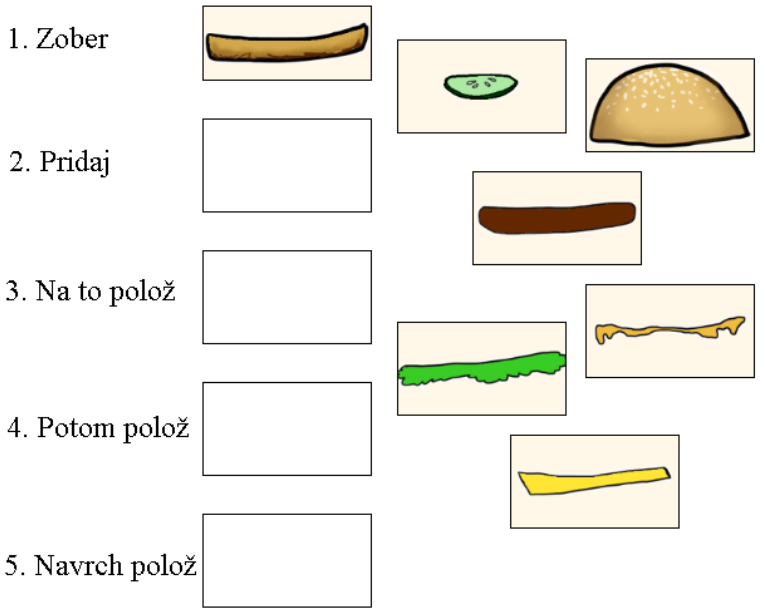

(Obr 1: Sút'ažná úloha Hamburger)

Jedným z mojich ciel'ov bolo vytvorit' sériu gradovaných úloh, ktoré by boli založené na princípe týchto troch vybraných sút’ažných úloh. Navrhla som dve vyučovacie hodiny, na ktorých žiaci tieto série riešili. Pri príprave úloh na vyučovacie hodiny som kládla vel'ký dôraz na jasnú formuláciu hlavných a čiastkových edukačných ciel'ov. Okrem toho som zostavila tieto hodiny tak, aby sme sa venovali aj vyšším kategóriám Bloomovej taxonómie ako analýza, syntéza a hodnotenie (nielen jej nižším kategóriám: znalosti, porozumenie a aplikácia), pozri [4].

\section{Východiská k uskutočneným hodinám}

Uvedené plány na vyučovacie hodiny som si pripravila pôvodne pre tretí ročník prvého stupňa ZŠ. Rozhodla som sa, že overenie týchto návrhov prevediem počas vyučovania na neplnoorganizovanej základnej škole, kde učím.

Druhý a tretí ročník, v ktorých vyučujem, majú spoločne hodinu informatickej výchovy. Druháci sú piati a tretiaci traja. Tiež je dôležité si uvedomit', že v triede je iba jeden stolný počítač. Pani riaditel'ka mi však poskytla na tieto hodiny aj svoj notebook, ja ešte nosím žiakom svoj vlastný. Takto mám $\mathrm{k}$ dispozícii tri počítače pre osem žiakov. Toto sú dôvody, prečo bolo treba upravit' moje pôvodné prípravy na hodiny podl'a konkrétnej situácie.

\section{Príprava prvej vyučovacej hodiny na tému „Skladanie podl'a predlohy“}

Tematický celok: Postupy, riešenie problémov, algoritmické myslenie

Téma: Skladanie podl'a predlohy

Hlavný ciel' hodiny: Rozvíjat' schopnost' žiakov skladat' podl'a predlohy

Čiastkové ciele: Žiaci po tejto vyučovacej hodine:

- budú schopní pracovat' podl'a návodu,

- dokážu nájst' a opravit' chybu v návode,

- dokážu vytvorit' jednoduchý návod,

- dokážu zoradit' jednotlivé kroky návodu do správneho poradia.

Typ vyučovacej hodiny: Kombinovaná hodina Organizačná forma: Skupinová aj individuálna Vyučovacie metódy: Motivačný rozhovor, manipulácia s predmetmi, práca pri počítači

Učebné pomôcky: Drevené stavebnice, vystrihnuté papierové časti hamburgera, pripravené aktivity na počítači

Fakty a pojmy: Postup, návod, recept

Digitálne zručnosti:

- klikanie myšou,

- t'ahanie objektov,

- práca so súbormi - otváranie, zatváranie, premenovanie

\section{Spôsob osvojovania:}

- práca s reálnymi objektmi,

- zostavovanie a zorad'ovanie návodu,

- didaktické hry a skladačky

\section{Nie je ciel'om}

- ovládanie softvéru, 
- rýchle riešenie problémov bez premýšl’ania

\section{Medzipredmetové vzt'ahy}

- informatická výchova a matematika, pracovné vyučovanie, prírodoveda

Prvá naplánovaná hodina bola zameraná na Skladanie podl'a predlohy. Vybrala som si pre ňu spomínané úlohy Hamburger a Kocky.

Jedným z mojich ciel'ov bolo ukázat' učitel'om, že podl'a vybraných sútažných úloh sa dajú vytvorit' aktivity na hodinu informatickej výchovy, ktoré nevyžadujú použitie počítačov. Následne sa na tieto úlohy dá nadviazat' s aktivitami, ktoré prebiehajú pri počítači.

Vyučovaciu hodinu som začala motivačným rozhovorom, ktorým som vzbudila záujem žiakov o tému hodiny. Tento rozhovor slúžil najmä na to, aby pomohol žiakom spomenút' si, $\mathrm{v}$ akých situáciách sa stretli $\mathrm{s}$ pojmami postup, návod či recept. Navzájom si vysvetlili, ako chápu tieto pojmi. To im pomohlo lepšie porozumiet' týmto pojmom.

Na prvú čast’ hodiny som navrhla dve aktivity, ktoré nevyžadujú použitie počítača. Týmito aktivitami som nadviazala na vybrané sút'ažné úlohy a na predošlé vedomosti žiakov.

Prvá aktivita vychádzala $\mathrm{z}$ úlohy Hamburger. Každý žiak dostal nastrihané kúsky papiera t.j. kartičky, ktoré predstavovali jednotlivé časti hamburgera. Pomocou týchto papierových kartičiek mohol vyrobit' celý hamburger. Zadanie malo viacero riešení, podl'a toho, akú predlohu dostal žiak na obrázku.

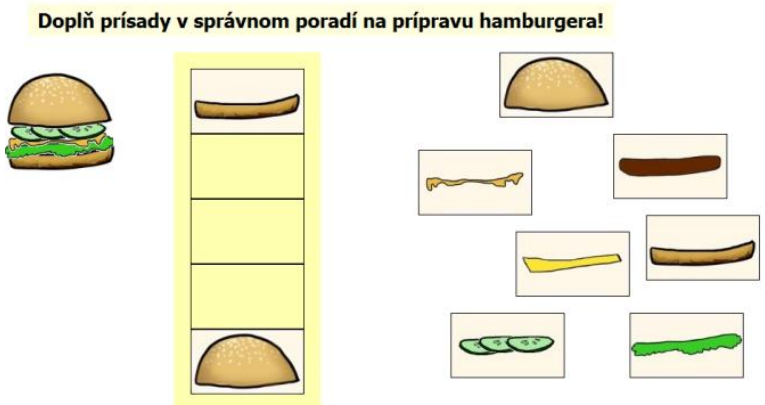

(Obr 2: Predpripravená úloha Hamburger čislo 3, rozloženie plánovaných krokov ,pod seba“)

Témou druhej aktivity bolo skladanie „vežičiek“ z drevených kociek, podobne ako v úlohe Kocky. Pre väčšinu žiakov by mali byt' tieto kocky intuitívne a známe. Z pozorovania skutočne vyplynulo, že deti vedia s nimi narábat'. Každý žiak dostal jednu drevenú kocku, potom som im všetkým ukázala obrázok vežičky, ktorú mali postavit' pomocou kociek, ktoré majú v rukách. Žiaci museli dávat' pozor, v akom poradí majú klást' kocky na seba. Touto aktivitou sme rozvíjali nielen ich schopnost' skladat' podl'a predlohy, ale aj schopnost' kooperácie a komunikácie so spolužiakmi. Súčast'ou tejto úlohy bolo postavit' sa do radu v poradí podl'a toho, ako mali klást' svoje kocky pri stavbe vežičky. Táto čast' hodiny bola zameraná na rozvoj tretej úrovne Bloomovej taxonómie, a to aplikovat'.

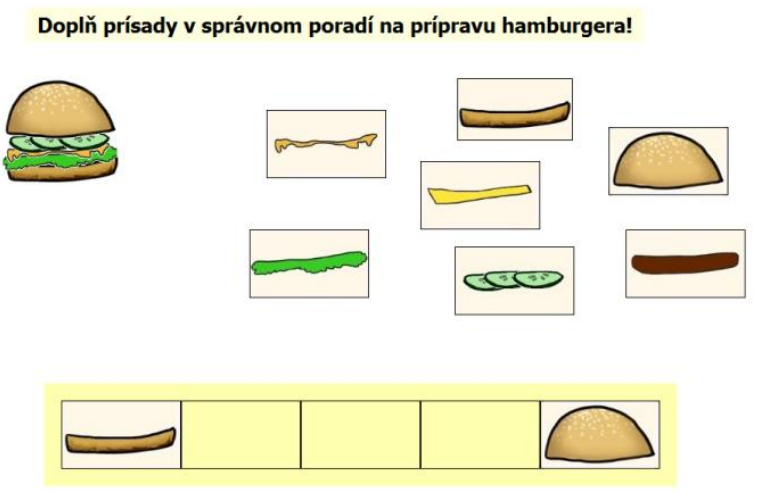

(Obr 3: Predpripravená úloha Hamburger čislo 3 , rozloženie plánovaných krokov ,vedl'a seba“)

$\mathrm{Na}$ základe vybraných sút'ažných úlohách som pre žiakov navrhla aj sériu gradovaných počítačových úloh. Takto vznikli dve série úloh po 9 zadaní. Gradáciu som vytvorila nielen zvyšujúcou sa komplexnost'ou úloh, ale aj sledovanými ciel'mi z Bloomovej taxonómie. Zamerala som sa na jej vyššie úrovne: analyzovat', tvorit' a hodnotit'. Toto je znenie zadaní zo série mojich úloh:

Hamburger

- Ktorá prísada chýba? (1)

- Doplñ prísady v správnom poradi na prípravu hamburgera! (3) (pozri Obr 2 a Obr 3)

- Pri priprave hamburgera sa stala chyba. Výmenou kartičiek oprav postup! (2)

- Vakom poradi sa pridávajú prísady pri príprave hamburgera? (3)

Kocky

- Ktorá drevená kocka Ti chýba, ak chceš postavit' takúto vežičku? Prines ju na vol'né miesto! (1)

- Dopln̆ drevené kocky v správnom poradí, aby si mohol postavit’ takúto vežičku. (2)

- Pri stavbe vežičky sme sa pomýlili. Výmenou drevených kociek oprav chybu! (3) (Obr 5)

- Na vyznačené miesta prines kartičky s drevenými kockami v takom poradi, v akom ich budeš ukladat', aby si postavil takúto vežičku. (3)

Č́sla v zátvorkách označujú výskyt otázky v celkovej sérií úloh. 
Pri príprave úloh som použila bežné nástroje, ktoré môžu mat' učitelia $\mathrm{k}$ dispozícii: Imagine Logo a Kartičky. Aktivity na prvú hodinu som si vytvorila pomocou prostredia Kartičky. Na túto hodinu som vytvorila štyri druhy úloh aj pre Hamburger aj pre Kocky. Najprv bolo treba nájst' jednu chýbajúcu kocku, resp. ingredienciu. Druhý typ úloh bol podobný, bolo treba doplnit' viaceré chýbajúce kartičky, pozri $\boldsymbol{O b r} 2$ a $\boldsymbol{O b r} 3$. Tretí typ úloh si už vyžadoval kritické myslenie žiakov. V zadaní úlohy sa im predkladal nesprávny postup riešenia, pričom úlohou žiaka bolo tento postup opravit' (Obr 5). Posledné úlohy boli zamerané na vol'nú tvorbu: žiaci mali vytvorit' celý postup skladania samostatne.

Na vyznačené miesta prines kartičky s drevenými kockami v takom poradí, v akom ich budeš ukladat, aby si postavil takýto hrad:

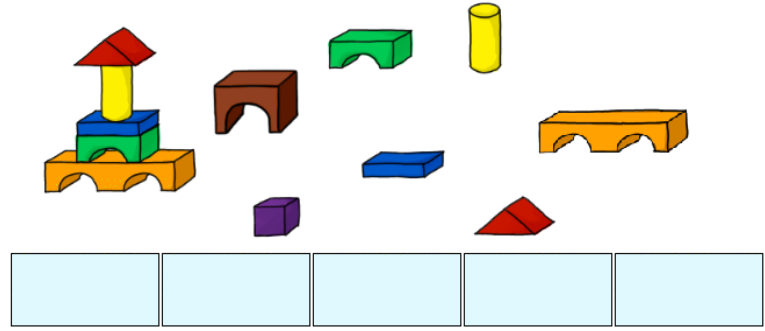

(Obr 4: Sútažná úloha Kocky)

\section{Priebeh prvej vyučovacej hodiny}

Hodinu som začala motivačným rozhovorom. Prvá otázka znela: Viete mi povedat', čo je to postup? Žiaci sa snažili spojit' tento pojem s počítačom - zrejme preto, že sme práve mali hodinu informatickej výchovy. Pomocou tejto otázky sme sa dostali k pojmu „návod“. Pýtala som sa žiakov, či už videli niekde návod. Prvé, čo im prišlo na um, bola stavebnica Lego, rôzne hračky či videá s návodmi. Potom som sa ich spýtala, či už niekedy videli svoje mamy varit'. Použivajú pri vareni recepty? Táto otázka prebudila ich fantáziu. Jeden po druhom hovorili recepty, ktoré poznali. Potom som prešla na najjednoduchšie recepty. Vybrali sme si prípravu kávy. Pri opise týchto jednoduchých receptov si žiaci mali možnost' uvedomit' dôležitost' poradia pri vykonávaní jednotlivých krokov.

Po úvodnej časti hodiny som prešla $\mathrm{k}$ úlohám bez počítača. Téma bola rovnaká. Recepty, konkrétne príprava hamburgera. Reakcie žiakov boli jasným znamením, že vol'ba takejto témy bola vhodná. Každý žiak dostal sedem kartičiek s prísadami hamburgera, spolu s obrázkami hotových hamburgerov. Podla týchto predlôh si mali vybrat' správne kartičky a usporiadat' prísady do správneho poradia. Aj ked' nepracovali s počítačmi, táto aktivita ich zaujala.
Po tejto aktivite som rozdala žiakom drevené kocky. Tretiaci dostali po dve, druháci po jednej. Podl'a obrázka mali poskladat' stavbu z kociek. Žiaci boli prekvapení, že mali spolupracovat'. „Všetci?" Nevedeli si predstavit', ako môžu postavit' vežičku, ked' majú v ruke len jednu, alebo dve kocky, kým neuvideli svoju kocku na obrázku. Potom už bez t’ažkostí postavili vežičky z obrázkov. Vždy sa našiel niekto, kto ostatným radil a usmerňoval ich.

Prešla som k druhej časti hodiny. Druháci si sadli $\mathrm{k}$ počítačom. Dala som im pokyny k počítačovým úlohám a zdôraznila som, aké dôležité je pozorne si prečítat' zadanie pri každej úlohe. Potom začali pracovat' samostatne. Ak mali otázky k úlohám, opýtali sa ma.

Tretiaci zatial' stavali vežičky z kociek podl'a vlastnej fantázie. Jedna žiačka chcela tiež nástojčivo pracovat's počítačom, kým som sa im nezačala venovat' a neukázala som im zložitejšie stavby, ktoré mali poskladat'. Táto žiačka bola hlavná iniciátorka skupiny, každú kocku chytila a premiestnila. Žiaci tieto vežičky stavali s nadšením. Ked' druháci dokončili prácu na počítačoch, skupiny sa vymenili.

V oboch skupinách sa našiel žiak, ktorému spôsobovalo t'ažkosti spolupracovat' s ostatnými, napr. im ničil už postavenú stavbu. Druháci sa pri stavaní hádali menej ako tretiaci a dokázali sa dohodnút'. Je zaujímavé, že u druhákov bol hlavnou iniciátorkou dievča, rovnako ako u tretiakov. Ked' pracovali bez návodu, s nadšením mi oznamovali, že sa im podarilo postavit' obrovskú stavbu zo všetkých kociek. Pri tejto úlohe jeden zo žiakov komentoval, že mu chýbajú hotové obrázky, čiže návody. Ked' dostali konkrétny návod, čo majú postavit', aj on dokázal spolupracovat's ostatnými.

Po týchto aktivitách nasledovala d'alšia výmena. Druháci začali riešit' počítačové úlohy zamerané na kocky, tretiaci dostali kartičky s prísadami hamburgera.

Toto kolo už bolo ovel'a rýchlejšie. Žiaci presne vedeli, čo ich čaká. Všetky počítačové úlohy totiž mali rovnaké ovládanie, a teda ho už poznali. Skupina, ktorá riešila kartičkové úlohy, vedela, že sa opät' dostane $\mathrm{k}$ počítačom, takže sa dokázali sústredit' na svoje zadanie. Najprv poskladali všetky hamburgre, ktoré boli pripravené na predlohách. Po tejto úlohe dostali nové zadanie. Jeden z nich hovoril (diktoval) ostatným, aké prísady majú pridat' do svojho hamburgera a $\mathrm{v}$ akom poradí. Táto úloha $\mathrm{sa} \mathrm{im}$ skutočne páčila. Poskladali si aj „extradvojité burgre". 
Nasledovala posledná výmena skupín medzi počítačmi a papierovými aktivitami. Na konci hodiny som sa opýtala žiakov, ktoré aktivity sa im páčili najviac. Nevedeli si vybrat'. Podl'a ich slov sa im páčili aj počítačové aj papierové úlohy, čo pri tejto vekovej kategórií je pozoruhodné. Zo skúseností viem, že títo žiaci by najradšej sedeli celý deň pri počítači a hrali by sa. Žiaci tiež povedali, že tieto úlohy neboli pre nich náročné a všetko l'ahko zvládli. Zaujímavé však je, že z ich výsledkov vidno, že neriešili všetky úlohy úplne správne.

Pri stavbe vežičky sme sa pomýlili. Výmenou drevených kociek oprav chybu!

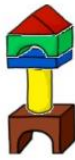

\section{五}
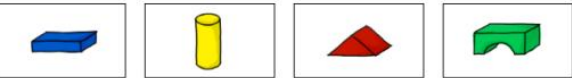

(Obr 5: Predpripravená úloha Kocky, číslo 6)

Na čo si musí učitel' pri takejto hodine dávat' pozor? Pri aktivite hamburger si žiaci nedávajú pozor na poradie, $\mathrm{v}$ akom sa reálne hamburger pripravuje. Ked' však pracujú s vytlačenými alebo počítačovými kartičkami, bez problémov dokážu skladat' hamburger od vrchu. Samozrejme, pri príprave ozajstného hamburgera je to nemožné. Treba sa o tom porozprávat' na začiatku hodiny.

Učitel' sa môže rozhodnút', aké poradie úloh si zvolí. Samozrejme, rôzne kombinácie skrývajú rôzne výhody aj nevýhody. Na učitel'ovi ostáva aj návrh a formulácia riešení počítačových úloh. Môže si vyskúšat', aká možnost' je prirodzená pre žiakov a aká nie je, napr. poukladat' prísady hamburgera pod seba (Obr 2) alebo vedla seba (Obr 3).

\section{Príprava druhej vyučovacej hodiny na tému "Riadenie robota“"}

Tematický celok: Postupy, riešenie problémov, algoritmické myslenie

Téma: Riadenie robota

Hlavný ciel' vyučovacej hodiny: rozvíjat' schopnost' žiakov riadit' robota

Čiastkové ciele: Po tejto hodine žiaci:

- budú schopní zadávat' príkazy na ovládanie robota $\mathrm{v}$ priamom režime,

- dokážu hodnotit' správnost' ponúkanej cesty postavičky,
- dokážu interpretovat' jednoduché algoritmy $\mathrm{v}$ detskom programovacom prostredí na riadenie robota.

Typ vyučovacej hodiny: Kombinovaná hodina Organizačná forma: Skupinová, individuálna Vyučovacie metódy: motivačný rozhovor, manipulácia s predmetmi, práca pri počítači

Učebné pomôcky: kreslená mapa, figúrky, pripravené aktivity na počítači

Fakty a pojmy: riadenie robota, postupnost' krokov, elementárne príkazy

Digitálne zručnosti:

- klikanie myšou,

- t'ahanie objektov,

- práca so súbormi - otváranie, zatváranie.

Spôsob osvojovania:

- ovládanie robota (figúrky) v skutočnosti,

- ovládanie robota $\mathrm{v}$ počítačovom prostredí,

- didaktické hry.

\section{Nie je ciel'om}

- ovládanie softvéru,

- rýchle riešenie problémov bez premýšl'ania.

\section{Medzipredmetové vzt'ahy}

- informatická výchova a matematika, pracovné vyučovanie, prírodoveda.

Podobne ako na prvej hodine, aj tu som začala motivačným rozhovorom, aby si žiaci spomenuli na predchádzajúce skúsenosti s robotmi.

Témou druhej hodiny bolo Riadenie robota. Túto hodinu inšpirovala aktivita z pilotného ročníka kategórie Bobrik - Myš a syr. Pri návrhu aktivít som však zmenila hlavnú postavu, ktorú mali žiaci riadit'. Na úvodnú aktivitu som si pripravila mapu s rozprávkou a s rôznymi postavičkami. Pre úlohy na počítači som si vybrala včielku, ktorá mala lietat' ku kvietkom.

Ako úvodnú aktivitu som nakreslila jednoduchú mapu v tvare štvorcovej siete (7x7). Pripravila som malé figúrky - postavičky, žijúce na mape - a k nim rozprávku. Každý žiak si vybral postavičku, ktorá sa mu páčila, a položil ju na mapu, do jedného zo štvorcov. Potom si vypočuli rozprávku: na mape žijú rôzne postavičky (duch, korytnačka, mimozemšt’an, človeče figúrka...). Poznajú len to, čo je v ich dedinke, teda len to, čo je nakreslené na mape. Vedia, ktorým smerom od nich je psík, domček, kvetinka a stromček - tieto veci sú na mape nakreslené a nahradzujú smery ako hore, dolu, vpravo a vlavo. Postavičky sa môžu teda pohybovat' vždy jedným z týchto štyroch smerov.

Aktivita $\mathrm{k}$ tejto mape je nasledujúca: žiaci majú dávat' príkazy postavičkám žijúcim na mape, ktoré rozumejú len príkazom v tvare: meno postavičky, + "chod" smerom $\mathrm{k}$ " + meno obrázka 
nahradzujúceho smer + ,počet krokov“. Napr.: „Duch, chod' smerom ku kvietku 3 kroky.“ Postavičky žijúce na mape môžu vykonat' len tie príkazy, na ktoré majú dost' miesta. Žiadnym iným príkazom nerozumejú. Ak by mali spravit' viac krokov ako môžu, radšej ostanú na mieste.

Takouto hrou si mali žiaci precvičit' ovládanie „robota“ a porozumiet' mu. Spoznali presné príkazy a ich použitie. Po tejto aktivite nasledovali pripravené úlohy pri počítači.

Na základe sútažnej úlohy Myš a syr som navrhla devät' gradovaných zadaní, pričom niektoré obsahujú viac podúloh. Ciel'om týchto aktivít je, aby žiaci dokázali aplikovat' nadobudnuté skúsenosti s ovládaním postavičiek, analyzovat' správnost' umiestnenia šípok a hodnotit' ponúkané možnosti riešenia. Hlavnou úlohou je dostat' včielku ku kvietku a žiaci jej majú pritom pomôct'. Prvá aktivita nemá zadanie. Slúži na zoznámenie žiaka s prostredím, kde si žiaci môžu vyskúšat' ovládanie včielky. Ostatné aktivity majú nasledujúce zadania:

\section{Pomôž včielke dostat'sa ku kvietku!}

3., 4. Ulož chýbajúce šipky tak, aby sa včielka dostala ku kvietku! Použi všetky šipky! (Obr 7)

5. Pomôž včielke dostat' sa ku kvietku čo najkratšou cestou!

Nájdi aj inú cestu rovnakej dĺžky!

6. Vyber si, ktorou cestou sa dostane včielka ku kvietku!

7. Vyber si, ktorou cestou sa nedostane včielka ku kvietku!

8. Vyber si, ktorou cestou sa dostane včielka ku kvietku! Pozor! Nad červenými múrmi nedokáže preletiet'.

9. Vyber si, ktorou cestou sa dostane včielka ku kvietku!

Úlohy s číslom 2 a 5 obsahujú niekol'ko podúloh. V nich východzie pozície včielky a kvietku sú často rovnaké, líšia sa len v zadaní. Tretia a štvrtá úloha má viacero riešení. Posledné štyri obsahujú štyri možné odpovede, z ktorých si žiaci majú vybrat' tú správnu, čiže tú, ktorá je odpoved'ou na otázku v zadaní. Deviata aktivita je kombináciou 6., 7. a 8. úlohy. Sledovala som pozornost' žiakov, preto má každá podúloha iné zadanie. Tak isto pri siedmej, kde je otázka formulovaná pomocou záporu.

\section{Priebeh druhej vyučovacej hodiny}

Druhú naplánovanú hodinu som si musela rozdelit' na dve vyučovacie hodiny, ked'že boli potrebné tri výmeny pri počítačoch, čo sa nedalo stihnút' za 45 minút.

Hodinu som začala otázkou, čo je to príkaz. Dostala som rôzne odpovede: „Príkaz je, čo mám robit'." „Mne mama dáva prikazy." Potom sme prešli k hračkám. Žiaci vymenovali tie, ktoré fungujú na dial'kové ovládanie.

Po rozhovore som ukázala žiakom mapu, ktorú som pripravila. Vybrali si postavičky, ktoré sa im páčili najviac a poukladali ich na ňu. Následne si vypočuli rozprávku $\mathrm{k}$ mape a po jednom dávali postavičkám príkazy. Malý problém im robilo zapamätat' si presné znenie príkazu. Zabudli bud' zadat' smer, alebo počet krokov. Často oslovovali žiaka, namiesto konkrétnej postavičky. Napriek týmto t’ažkostiam sa im táto aktivita páčila a s vel'kým nadšením vymýšlaali príkazy. Brali ju ako hru, dokázali sa vžit' do rozprávky, a aj preto ju považujem za úspešnú.

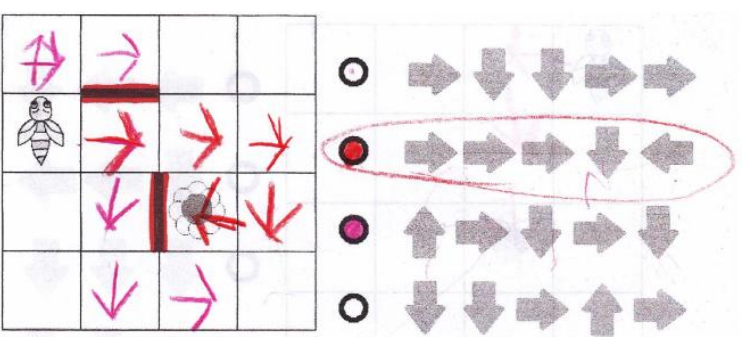

Vyber si, ktorou cestou sa dostane včielka ku kvietku! Pozor! Nad červenými múrmi nedokáže preletiet.

(Obr 6: Jedno riešenie vytlačenej úlohy Včielka, číslo 8)

Po úvodnej aktivite sme prešli k riešeniu pripravených úloh. Na tejto hodine bol prítomný každý žiak, musela som ich preto rozdelit' až na tri skupiny. Najprv riešili počítačové úlohy traja tretiaci. Niektoré podúlohy $\mathrm{z}$ posledných štyroch úloh (z pripravených deviatich) som vytlačila žiakom na papier (napr. $\boldsymbol{O b r}$ 6), takže pri počítači im ostalo na riešenie pät' úloh. Tretiakom som vysvetlila, ako fungujú počítačové aktivity, aké je ich ovládanie a zdôraznila som, že si majú pozorne čítat' zadanie pri každej z nich. Najväčšie problémy a najviac otázok vyvolávala tretia úloha, pozri Obr 7. 


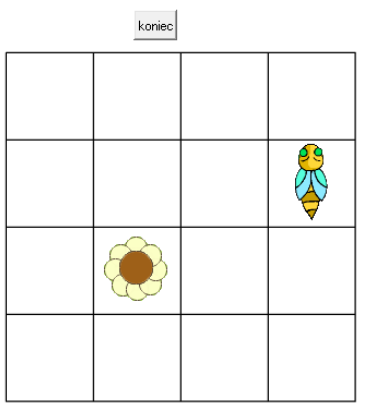

Ulož chýbajúce šípky tak, aby sa včielka dostala ku kvietku!

Použi všetky šípky!
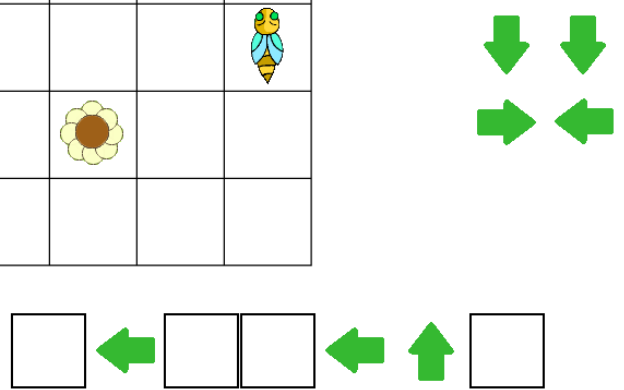

(Obr 7: Predpripravená úloha Včielka, číslo 3)

Žiakom, ktorí riešili úlohy vytlačené na papieri, som povedala len tol'ko, že si majú prečítat' zadanie. Avšak len podl'a prečítaného zadania nevedeli, čo majú robit'. Potrebovali podrobnejšie vysvetlenie. Nakoniec rôznymi farbami kreslili možné cesty priamo do mapy. Ďalšiu skupinku pri počítačoch tvorili dve druháčky. Ostatným druhákom, ktorí už vyriešili vytlačené aktivity, som zadala zasa inú úlohu. Do zošita si mali napísat' tri l'ubovol'né príkazy, ktoré na konci hodiny zadajú spolužiakom. Toto zadanie nebolo pre žiakov nové, ked’že sme podobnú aktivitu robili aj na predošlej hodine. Po úvodných t'ažkostiach si s vel'kým nadšením vymýšl’ali rôzne príkazy.

Ďalší týždeň sme spravili poslednú výmenu. Posledná skupina žiakov dostala možnost' vyriešit' úlohy s včielkou pri počítači. S ostatnými žiakmi sme sa zatial” ,pohrali“" s mapou. Ešte raz sme si podrobne vysvetlili, ako sa môžu pohybovat' postavičky po mape a aké smery poznajú. Povedali sme si tiež presnú pozíciu každej figúrky. Tým sme si nacvičili, ako si môžu napr. na šachovnici určit' presnú pozíciu šachovej figúrky.

Jeden žiak pri počítači nerozumel, ako treba vyriešit' tretiu úlohu. Vel'mi mu vadilo, že sa včielka nepohla, ked' klikol na niektorú šípku. Až po mojom dlhom vysvetl'ovaní sa dostal do stavu, že bol ochotný aspoň porozmýšl'at' nad riešením.
Ktorou cestou sa dostane myška ku syru?

Myška sa bude pohybovat' podl'a šípiek po čiarach.

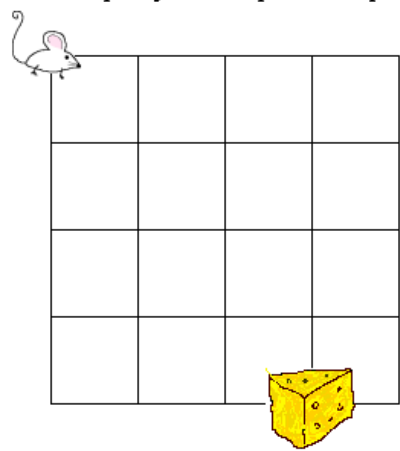

a.

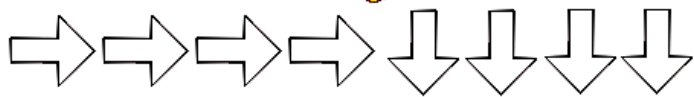

b.

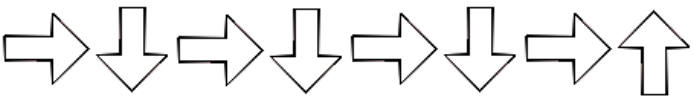

c.

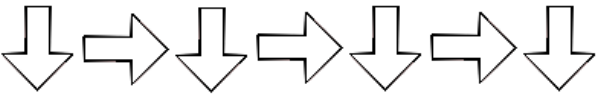

d.

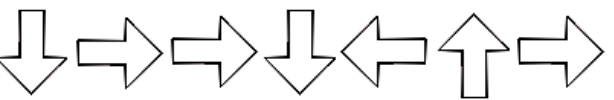

(Obr 8: Sútažná úloha Myš a syr)

$\mathrm{Na}$ čo si treba dat' pri takejto hodine pozor? $\mathrm{V}$ prvom rade by si učitel' mal vyskúšat' počítačové aktivity ešte pred vyučovacou hodinou. Mal by sa uistit', že sa dajú spustit' na počítačoch, ktoré má $\mathrm{k}$ dispozícii v škole, kde učí. Často sa stáva, že kvôli technickým problémom nie je možné zrealizovat' naplánovanú hodinu.

Ak si učitel' pripraví podobnú mapu ako som opísala, musí si premysliet' všetky možné problémy, ktoré sa môžu vyskytnút'. Napr. obrázky smerov by nemali byt' rovnaké s postavičkami, ktoré použije. Tým sa zaručí jednoznačnost' pri oslovovaní postavičky a určovaní smeru. Tiež si treba vybrat' vhodné umiestnenie obrázkov, aby bol žiakom jasný smer, ktorým sa má pohnút' ich figúrka. Môže sa stat', že si žiaci zle interpretujú smer a pochopia ho ako konkrétne políčko na mape.

Žiaci si neradi čítajú zadania. Často si v duchu vytvorili k obrázkom vlastnú verziu zadania a potom boli presvedčení, že mali riešit' práve to. Takto vznikajú rôzne chybné riešenia.

Počas vyučovania sa môže stat', že žiaci dokončia danú úlohu skôr, alebo kvôli technickým problémom nie je možné nasadit' nejakú aktivitu zo série úloh. Práve preto musí mat' učitel' vždy pripravený náhradný plán.

\section{Záver}

Po testovaní navrhnutých úloh môžem konštatovat', že žiaci ich riešili so záujmom. Je to dobrý 
dôkaz toho, že pomocou dobre zvolenej motivácie môžeme získat' pozornost' žiakov. Žiaci, s ktorými som pracovala, si nečítali pozorne zadania úloh, hoci som ich na to viackrát upozornila. Radšej sa opýtali, čo treba robit', alebo si vytvorili vlastnú verziu zadania.

V článku som opísala návrh a priebeh dvoch konkrétnych vyučovacích hodín, ktoré boli zamerané na tematický celok Riešenie problémov a algoritmické myslenie. Aktivity, ktoré boli súčast'ou vyučovacích hodín boli inšpirované úlohami zo sút'aže iBobor.

Ciel'om článku bolo ukázat' učitel’om, ako užitočne môžu využit' už hotové, naformulované sút’ažné úlohy a s minimálnou námahou si môžu pomocou nich pripravit' celú vyučovaciu hodinu - od motivácie až po hodnotenie. Takúto pomoc poskytuje iBobor nie len pre jeden tematický okruh, ale pre každý, nakol'ko sa táto sút'až snaží zahrnút' všetky témy školskej informatiky.

\section{Literatúra}

[1] HRUŠECKÁ, A. et al. Informatický bobor Nová sút’až $v$ informačných technológiách pre žiakov základných a stredných škôl. In: DidInfo 2008. Banská Bystrica, ISBN 978-808083-556-9.

[2] Stránka sút'aže iBobor: <http://ibobor.sk/>.

[3] ŠVAŘíČEK, R., ŠEĎOVÁ, K. et al. Kvalitativní výzkum v pedagogických vědách. (2007) Praha: Portál. ISBN 978-80-7367-313-0.

[4] PASH, M. et al. Od vzdělávacího programu k vyučovací hodině. (1998) Praha: Portál. ISBN 80-7367-054-2.

Mgr. Monika Gujberová

Katedra základov vyučovania informatiky

Fakulta matematiky fyziky a informatiky, UK Mlynská dolina 1

842 48, Bratislava, $S R$

Tel: +421 260295611

E-mail: monika.gujberova@fmph.uniba.sk Www pracoviska: http://edi.fmph.uniba.sk/ 